\title{
CELANI, M. A.; FREIRE, M. M.; RAMOS, R. C. G. (Org.). A abordagem instrumental no Brasil: um projeto, seus percursos e seus desdobramentos. Campinas: Mercado de Letras, 2009.
}

Kleber Aparecido da Silva*

Universidade de Brasília

Brasília - Distrito Federal / Brasil

\begin{abstract}
"Olhando para o passado, seguindo rumo ao futuro... Nada começa de repente, nem se sustenta no vazio. Nada vinga de semente infértil em solo improdutivo, nem floresce sem determinação e cuidados. Nada evolui se não de raízes potencialmente fortes, nem se desenvolve sem desbravar seus próprios caminhos. Nada conquista espaço sem exercitar um vir-a-ser diário e se responsabilizar pelo próprio percurso, sobrevivendo a obstáculos, preconceitos e mitos, fortificando-se nos desencontros. Nada escreve e reescreve a própria história, sem resgatar memórias, sem construir e reconstruir, continuamente, a própria identidade. Assim são as grandes ideias, os projetos de trabalho e de vida, as grandes realizações. Assim se caracteriza a Abordagem Instrumental no Brasil."
\end{abstract}

(FREIRE, 2009, p.11 - Ênfase adicionada)

\section{A obra, os autores e seus artigos}

O livro "A abordagem instrumental no Brasil: um projeto, seus percursos e seus desdobramentos", organizado pelas estudiosas da língua(gem), Maria Antonieta Alba Celani, Maximina M. Freire e Rosinda de Castro Guerra Ramos, da Pontifícia Universidade Católica de São Paulo (PUC-SP), é uma das onze obras que compóem a série "As faces da Linguistica Aplicada" (sendo

*kleberunicamp@yahoo.com.br 
a de no 10) e que tem por objetivos: “(...) contribuir para esclarecer e fortalecer as relaçōes entre as várias áreas da interação humana que envolvem a linguagem e que se entrecruzam e atravessam o terreno trandisciplinar da Linguística Aplicada (doravante LA) e, ao mesmo tempo, divulgar resultados de pesquisas, oferecendo materiais em português úteis para o desenvolvimento do saber em áreas tão diversas".

O referido livro está dividido em nove capítulos, precedido de uma "Apresentação" assinada pelas próprias organizadoras e de um "Prefácio" redigido pela linguista aplicada e uma das organizadoras do livro, Maximina M. Freire. Os capítulos são: "Revivendo a aventura: desafios, encontros e desencontros" (Maria Antonieta Alba Celani), "A história da abordagem instrumental na PUC-SP" (Rosinda de Castro Guerra Ramos), "Português Instrumental: um percurso" (Anna Maria Marques Cintra), "Trajeto do Francês Instrumental no Brasil' (Jelssa Ciardi Avolio), "O inglês instrumental na UFPE: contribuiçôes, tendências e mudanças" (Abuêndia Padilha Pinto), "A interface do projeto nacional ensino de inglês instrumental e a Universidade Federal de Uberlândia" (Célia Assunção Figueiredo), "A aventura do instrumental na UFRp” (Myriam Brito Corrêa Nunes), "Impact: What happens in the long run?" (John Holmes), "Literacy transfer: commonalities between research reports and advertising discourse as an aid to the teaching of reading in EAP" (Tom Deyes).

\section{A obra: finalidades, especificidades e possíveis desdobramentos}

Trata-se de um livro recente, de cunho retrospectivo e com alusóes prospectivas para a área de ensino de línguas para fins específicos, publicado em 2009, pela Mercado de Letras. A obra visa reunir releituras de textos de palestras e mesas redondas apresentadas no Seminário Comemorativo dos 25 anos do Projeto Ensino de Inglês Instrumental em Universidades Brasileiras (Projeto ESP), realizado na PUC-SP, de 14 a 15 de outubro de 2005.

Em síntese, o livro faz um resgate histórico desse Projeto e o circunscreve com o desenvolvimento da abordagem instrumental no ensino de línguas (inglês, português e espanhol), na PUC-SP e em algumas universidades federais do país (Universidade Federal do Pernambuco - UFPE, Universidade Federal de Uberlândia - UFU e Universidade Federal do Rio de Janeiro - UFRJ). Segundo as organizadoras, a obra visa, "(...) além de reunir histórias vividas, mas pouco contadas, também apresenta uma reflexão sobre o impacto de projetos e discute aspectos teóricos do discurso" (p. 186). Para tal intento, é apresentado, nos primeiros quatro capítulos da obra a trajetória da abordagem 
instrumental no Brasil, sinalizando, ao mesmo tempo, possíveis caminhos e desdobramentos, o que é contemplado com maior intensidade nos últimos cinco capítulos da obra.

A obra inicia-se com o artigo, a nosso ver seminal para a área de ensino de línguas para fins específicos, intitulado "Revivendo a aventura: desafios, encontros e desencontros", de autoria da mentora e coordenadora do projeto de ESP no Brasil, Professora Maria Antonieta Alba Celani, da PUCSP. Nesse artigo a autora traça um histórico do projeto desde as suas origens até os dias atuais. Os artigos redigidos por Rosinda de Castro Guerra Ramos, Anna Maria Marques Cintra, Jelssa Ciardi Avolio, Abuêndia Padilha Pinto, Célia Assunção Figueiredo e Myriam Brito Corrêa Nunes traçam a história da abordagem instrumental nas suas respectivas instituições de ensino, a saber, PUC-SP, UFPE, UFU e UFRJ.

O que nos chamou muita atenção nessa obra é a rica e vasta bibliografia em português, inglês e francês sobre a abordagem instrumental no ensino de línguas e que poderia ser utilizada como hipertextos para o entendimento mais sólido da referida área que tem despertado o interesse de inúmeros estudiosos do bojo da LA brasileira (CELANI et al., 2005; CELANI et. al., 1988)

\section{A obra: Possíveis encaminhamentos e considerações finais}

Pela variedade e abrangência dos artigos apresentados na obra, concluímos que o livro "A abordagem instrumental no Brasil: um projeto, seus percursos e seus desdobramentos" é de leitura essencial em cursos de LA, particularmente em nível de especialização e de mestrado / doutorado. Essa recomendação se deve ao caráter documental da obra e de suas contribuiçôes para possíveis desdobramentos.

Considerando o espírito cooperativo / colaborativo dos professores que fizeram / fazem parte desse projeto e a importância do ensino de línguas para fins específicos na sociedade brasileira, acreditamos que seria de suma importância a apresentação e discussão dos resultados de estudos empíricos que foram / estão sendo desenvolvidos em universidades públicas brasileiras (dissertaçōes / teses de doutorado) a partir deste relevante projeto, visibilizando, assim, não somente a "experiência acadêmica" mas o "fazer acadêmicocientífico", que se dá por meio da publicação dos resultados, por meio de artigos e livros como esse. 
Pensamos que seria procedente verter os textos para o inglês (e outras línguas estrangeiras) para publicação no Brasil, mas especialmente no exterior. Lamentavelmente nem todos os linguistas aplicados no exterior leem em português, fato que dificulta uma tomada de conhecimento do que se faz na LA brasileira e o que os linguistas aplicados têm a dizer. Quem sabe os organizadores se animam a elaborar, num futuro próximo, um livro nessa perspectiva? A nosso ver, será uma empreitada acadêmica, pioneira, inovadora e histórica no ensino de línguas para fins específicos, contribuindo assim para a consolidação dessa subarea na LA brasileira.

“(..) Fica o desejo de que, ao ler este volume, ao resgatar
e reviver uma história pioneira e bem-sucedida, possamos
articular alternativas de futuro que nos mobilizem a
registrar, daqui a algum tempo, novas memórias e a
continuidade de uma história que não termina aqui, não se
conclui agora.

(FREIRE, 2009, p. 13 - Ênfase adicionada)

\section{Referências}

CELANI, M. A. A.; DEYES, A. F.; HOLMES, J. L.; SCOTT, M. R. ESP in Brazil: 25 years of reflection and evolution. Campinas: Mercado de Letras, 2005. CELANI, M. A. A.; HOLMES, J. L.; RAMOS, R. C. G.; SCOTT, M. R. The Brazilian Esp Project: An Evaluation. São Paulo: EDUC, 1988.

FREIRE, P. Pedagogia do Oprimido. Rio de Janeiro: Paz e Terra, 2009. 